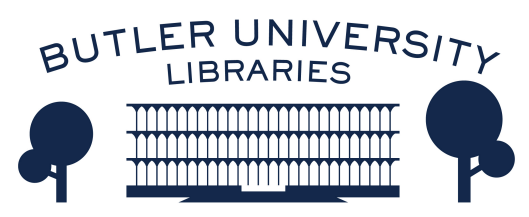

Journal of Hindu-Christian Studies

Volume 13

Article 21

January 2000

\title{
Book Review: "Asian Biblical Hermeneutics and Postcolonialism: Contesting the Interpretations"
}

M. Thomas Thangaraj

Follow this and additional works at: https://digitalcommons.butler.edu/jhcs

Part of the Religion Commons

\section{Recommended Citation}

Thangaraj, M. Thomas (2000) "Book Review: "Asian Biblical Hermeneutics and Postcolonialism: Contesting the Interpretations"," Journal of Hindu-Christian Studies: Vol. 13, Article 21.

Available at: https://doi.org/10.7825/2164-6279.1241

The Journal of Hindu-Christian Studies is a publication of the Society for Hindu-Christian Studies. The digital version is made available by Digital Commons @ Butler University. For questions about the Journal or the Society, please contact cbauman@butler.edu. For more information about Digital Commons @ Butler University, please contact digitalscholarship@butler.edu. 
from a biblical perspective. This is not, however, a naive restatement of traditional biblical Christianity. One of the most trenchant chapters of the book is entitled "A Catalogue of Traditional Christian Spirituality". It examines and critiques what many would consider the sacred cows of Christianity, viz. the spirituality of the martyrs, of the ascetics, of the monastics, of the mystics, of the Pietists and Puritans, and finds that all these, while exhibiting some genuine aspects of the Christian ethos, fall short of what is required today. Somendas develops his own thoughts in a section "Spirituality in the Light of the New Dharma". Clearly inspired by the Hindu notion of dharma as a paradigm for theological-ethical innovation, he proceeds to reconstruct a contemporary Asian Christian spirituality from the New Testament and key Christian theological elements.

Somendas gives much room to pioneer
Asian theologians, such as Toyohiko Kagawa and C. S. Song, and characterizes the "New Christianity" emerging from contemporary Asian theology as "third-eye", i.e. inspired, and not just rational, as people's theology, i.e. not the domain of academics, as ecumenical and relevant, implicitly rejecting much of Western Christian theology as too abstract, purely denominational, and narrow-minded.

The book is thought-provoking, filled with flashes of insight and pithy observations. It should stimulate especially younger Asian Christians to developing a dialogical theology and ethic in their own homelands. For academic Christian theologians in Western countries, it may be an eye-opener.

Klaus K. Klostermaier

Oxford Centre for Vaisnava and Hindu Studies

\section{Asian Biblical Hermeneutics and Postcolonialism: Contesting the Interpretations. R. S. Sugirtharajah. New York: Orbis Books, 1998, xii + $148 \mathrm{pp}$.}

COLONIALISM HAS PLAYED a significant role in the representation and interpretation of both Hindu and Christian religious traditions in India during and after the British rule in India. R. S. Sugirtharajah, a Sri Lankan theologian and a Senior Lecturer at Selly Oak Colleges in Birmingham, England, offers in this book a "resistant discourse which tries to write back and work against colonial assumptions, representations, and ideologies" (x). Here is a collection of essays that address the theme of postcolonial interpretation of the Bible. While some of the essays have already been published elsewhere, others are written specifically for this volume.

In Chapter 1, the author outlines the three prevalent modes of interpretation orientalist, anglicist, and nativistic - and offers a fourth option in his postcolonial criticism. The postcolonial option "involves the once-colonized 'Others' insisting on taking their place as historical subjects", offers a new identity to the interpreter, and unmasks "the link between ideas and power which lies behind Western texts, theories, and learning" (16ff.). Such an approach to the Bible looks for the "oppositional or protest voices within a text, refrains from romanticizing or idealizing the poor, refuses to blame the victims, and promotes "a wider hermeneutical agenda to place the study of sacred texts - Christian-Hindu, ChristianBuddhist, Christian-Confucian - within the intersecting histories which constitute them" (21-24). This chapter offers an excellent introduction to the whole project of the book. In the following chapters the author takes up some specific examples/events of textual interpretation and interprets them from the perspective of postcolonial criticism. For example, he analyses the 
biblical commentaries published during the colonial period, shows how these commentaries scripted India - the people and the culture - in particularly colonial ways. $\mathrm{He}$ points out that while "the commentaries proclaim the liberation that the gospel brings, the writers also replicate colonial attitudes and use rhetoric to redeem, educate, discipline, and convert Indians who are under their charge" (79).

Though the book is primarily on biblical hermeneutics, it addresses the issue of Hindu-Christian encounter in novel and interesting ways, especially in chapters 2 and 6. In "The Indian Textual Mutiny of 1820 " the author discusses "the interpretative skirmish" between the Christian missionary Joshua Marshman and the Hindu reformer Raja Ram Mohan Roy. The portrait of Roy that emerges in this chapter is refreshingly novel. The author ably shows that in the "skirmish" Roy comes as a victor with a better and interesting hermeneutics of the Bible than Marshman. While Marshman's interpretation of the Bible was "pietistic, sectarian, and hegemonic", Roy was able to perceive "a close interplay between interpretation and power" (42), and "rendered a valuable service by reasserting an aspect of Christianity [praxis] which the missionaries were overlooking" (45).

In the chapter entitled "Jesus in Saffron Robes? The 'Other' Jesus Whom Recent Biographers Forget", the author shows how the present-day biographers of Jesus "ignore the possible presence, impact, and contributions of Eastern thinking in the Mediterranean region during the time in which Christian faith emerged" (113). He

\section{Briefly Noted}

Hinduism: A Short History. Klaus K. Klostermaier. Oxford: One World Publications, $2000,342 \mathrm{pp}$.

One World's very useful, accessible, and reasonably priced series of short histories of the various traditions has added a fine treatment of Hinduism by Klaus calls for an engagement with the Asian concept of personality in understanding Jesus and his teachings, and a fresh understanding of the community of the faithful in light of the Eastern understandings of community. The issues raised in this chapter are highly relevant for those who seriously consider the future of HinduChristian relations in India and abroad. Sugirtharajah ends this brief chapter with an invitation to interreligious collaboration. $\mathrm{He}$ writes,
in a multireligious context like ours, the real contest is not between Jesus and other saviour figures like Buddha or Krishna, or religious leaders like Mohammed, as advocates of the "Decades of Evangelism" want us to believe, it is between mammon and Satan on the one side, and Jesus, Buddha, Krishna, and Mohammed on the other. Mammon stands for personal greed, avariciousness, accumulation, and selfishness, and Satan stands for structural and institutional violence. (119)

The book ends with a call to move away from easy and uncritical binary oppositions between East and West, Hindu and Christian, and Indian and Western, but to live with complexities of understanding. Not only biblical scholars but also those who are concerned with interreligious and intercultural relations will find this book extremely informative and illuminating.

\author{
M. Thomas Thangaraj \\ Candler School of Theology, \\ Emory University
}

Klostermaier. Chapter 1, the Introduction, discusses the term "Hinduism" and the problem inherent in offering a "History of Hinduism". It concludes with a discussion of the basic Hindu source literature. Chapter 2 offers a short history of two prominent Hindu centres, Mathura and Varanasi, which 